\begin{tabular}{|l|c|}
\hline MaR $201997(20)$ engineering data transmittal & Pao* 1 of $\frac{1}{1}$ \\
Ltta. 37 & 1. edt No 614621 \\
\hline
\end{tabular}

\begin{tabular}{|c|c|c|}
\hline $\begin{array}{l}\text { 2. To: (Receiving Organization) } \\
\text { Distribution }\end{array}$ & $\begin{array}{l}\text { 3. From: (originating Organization) } \\
\text { Solid Waste SAR Engineering }\end{array}$ & $\begin{array}{r}\text { 4. Related EDT No.: } \\
\text { N/A }\end{array}$ \\
\hline $\begin{array}{l}\text { 5. Proj./Prog./Dept./Div.: } \\
\text { Safety Analysis \& Nuclear } \\
\text { Engineering }\end{array}$ & $\begin{array}{l}\text { 6. Cog. Enigr.: } \\
\text { R. M. Irwin }\end{array}$ & $\begin{array}{l}\text { 7. Purchase Order No.: } \\
\text { N/A }\end{array}$ \\
\hline \multirow{2}{*}{\multicolumn{2}{|c|}{$\begin{array}{l}\text { 8. Originator Remarks: } \\
\text { Attached is the Central Waste Complex (Interim Operational } \\
\text { Safety Requirements (IDSRs) document, WHHE-SD-WM-TSR-005, } \\
\text { Revision O for approval. All review comments have been } \\
\text { resolved. }\end{array}$}} & $\begin{array}{l}\text { 9. Equip./Component No.: } \\
N / A\end{array}$ \\
\hline & & $\begin{array}{l}\text { 10. System/Bldg./Facility: } \\
\text { CWC } \\
\end{array}$ \\
\hline \multirow{3}{*}{\multicolumn{2}{|c|}{ 11. Receiver Remarks: }} & $\begin{array}{l}\text { 12. Major Assm. Dwg. No.: } \\
\text { N/A }\end{array}$ \\
\hline & & $\begin{array}{l}\text { 13. Permit/Permit Application No.: } \\
\text { N/A }\end{array}$ \\
\hline & & $\begin{array}{l}\text { 14. Required Response Date: } \\
\text { N/A }\end{array}$ \\
\hline
\end{tabular}

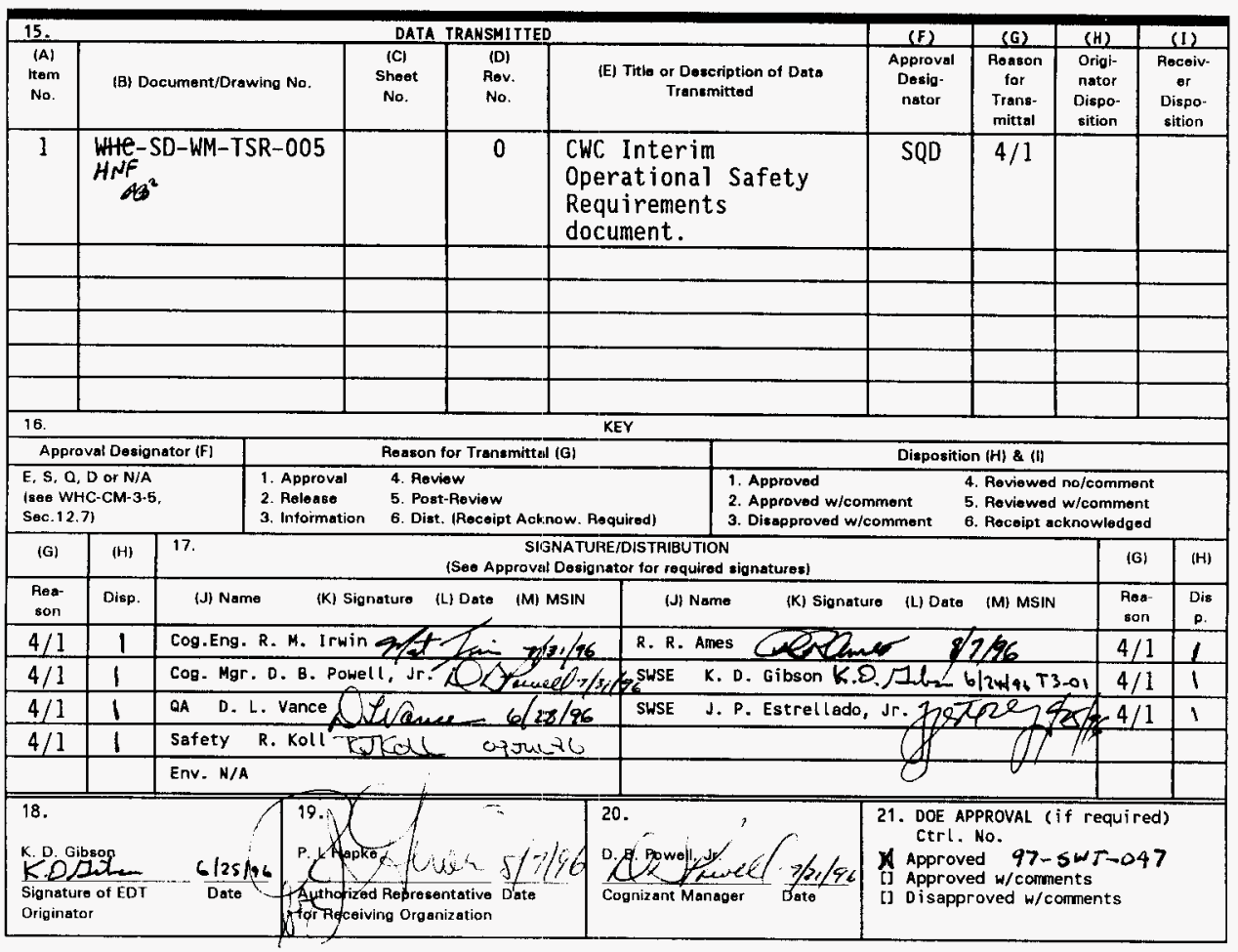




\title{
Central Waste Complex Interim Operational Safety Requirements
}

\author{
R.R. Ames, R.B. Bendixsen
}

Fluor Daniel Northwest, Richland, WA 99352

U.S. Department of Energy Contract DE-ACO6-96RL13200

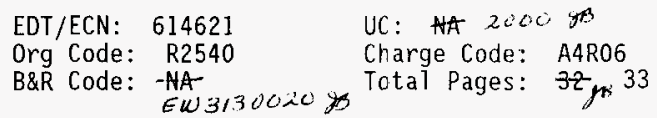

Key Words: Technical Safety Requirements, Central Waste Complex, Safety Analysis, Solid Wastes, Low-Level Wastes, Low-Level Mixed Wastes, TRU Wastes, Contact Handled Wastes

Abstract: This Interim Operational Safety Requirements document supports the authorization basis for interim operations and identifies restrictions on interim operations for the disposal and storage of solid waste in the Central Waste Complex. The Central Waste Complex Interim Operational Safety Requirements provide the necessary controls on operations in the Central Waste Complex to ensure the radiological and hazardous material exposure will be acceptable from an overall health and safety standpoint to the worker, the onsite personnel, the public and the environment.

TRADEMARK DISCLAIMER. Reference herein to any specific commercial product, process, or service by trade name, trademark, manufacturer, or otherwise, does not necessarily constitute or imply its endorsement, recommendation, or favoring by the United States Government or any agency thereof or $\mathrm{its}$ contractors or subcontractors.

Printed in the United States of America. To obtain copies of this document, contact: Document Control Services, P.O. Box 950, Mailstop H6-08, Richland WA 99352, Phone (509) 372-2420; Fax $(509) \quad 376-4989$.
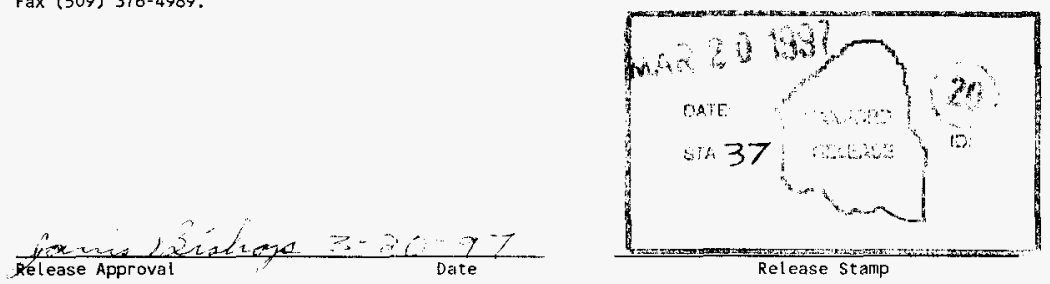

\section{Approved for Public Release}


HNF-SD-WM-TSR-005 REV 0

CENTRAL WASTE COMPLEX

INTERIM OPERATIONAL SAFETY REQUIREMENTS

Revision 0

March 1997 


\section{PREFACE}

The Central Waste Complex (CWC) Interim Operational Safety Requirements (IOSRs) specified in this document define acceptable conditions and administrative controls required to ensure safe operation of the CWC.

The format and content for this JOSR document is based on U.S. Department of Energy (DOE) Order 5480.22 (DOE 1992), DOE-STD-3009-94 (DOE 1994) and Westinghouse Hanford Company (WHC) policy on IOSRs.

The scope of this IOSR document is based on the CWC Interim Safety Basis (ISB) (HNF 1997) and supporting documents. The acceptable conditions and administrative controls set forth in this IOSR document are derived from the CWC safety analysis included in the CWC ISB. It is the responsibility of the CWC operations contractor to establish, implement, and maintain specific programs and procedures that meet the requirements of this IOSR.

The numbering and wording of the IOSR sections have been maintained for consistency with the WHC policy on IOSRs. The sections that are not applicable to CWC are noted throughout the IOSR document. 
PREFACE ............................ ii

TABLE OF CONTENTS .............................. . . . . . . .

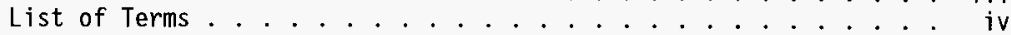

Section 1 USE AND APPLICATION . . . . . . . . . .... 1-2

1.1 Definitions ................... . . . . . .

1.2 Logical Connectors ................... . 1-3

1.3 Completion Times ................ . 1-3

1.4 Frequency ..................... . . . . . . . . . . .

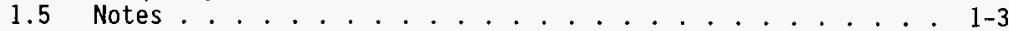

1.6 Modes . . . . . . . . . . . . . . . . . . . . . . 1-4

1.7 Safety Limits (SLs) . . . . . . . . . . . . . . 1-5

1.8 Limiting Control Settings (LCSs) . . . . . . . . . . 1-5

1.9 Limiting Conditions for Operation (LCOS) . . . . . . . 1-5

1.10 Surveillance Requirements (SRs) . . . . . . . . . 1-5

1.11 Administrative Controls (ACs) . . . . . . . . . . . 1-6

Section 2 SAFETY LIMITS ................ 2-2

2.0 Safety Limits (SLs) . . . . . . . . . . . . 2-2

Section 3 LIMITING CONDITIONS FOR OPERATION . . . . . . . . . . . . . . 3-2

3.0 Limiting Conditions for Operation (LCOS) . . . . . . . 3-2

Section 4 SURVEILLANCE REQUIREMENTS . . . . . . . . . . . . . 4-2

4.0 Surveillance Requirements (SRs) . . . . . . . . . . . 4-2

Section 5 ADMINISTRATIVE CONTROLS ............. 5-2

5.1 IOSR VIOLATIONS ..................... $5-2$

5.2 Organization ............... . . . . . .

5.3 Nuclear Criticality Safety . . . . . . . . . . . . . 5-6

5.4 Source Strength Control . . . . . . . . . . . . . 5-7

Section 6 REFERENCES ................ 6-2

Appendix A DESIGN FEATURES . . . . . . . . . . . . . A-2

Appendix B BASES ........................ B-2 


\section{List of Terms}

\begin{tabular}{ll} 
AC & Administrative Control \\
ALARA & As Low As Reasonably Achievable \\
CPS & Criticality Prevention Specification \\
DOE & U.S. Department of Energy \\
IOSR & Interim Operational Safety Requirement \\
ISB & Interim Safety Basis \\
LCO & Limiting Condition for Operation \\
LCS & Limiting Control Setting \\
NA & Not Applicable \\
PS0 & Program Secretarial Officer \\
SAR & Safety Analysis Report \\
SL & Safety Limit \\
TSR & Technical Safety Requirement \\
WHC & Westinghouse Hanford Company \\
\hline \hline
\end{tabular}




\section{SECTION 1}

USE AND APPLICATION 
Section 1 USE AND APPLICATION

1.1 Definitions

The defined terms of this section are unique definitions. They appear in CAPITALIZED type and are applicable throughout these IOSRS and BASES. Some terms refer the user to another Section for the definition. This has been provided to prevent a shortened definition from being supplied and used out of context.

\section{$\underline{\text { Term }}$}

BASES

CWC DE-Ci

DESIGN FEATURES

MODE

OPERABLE/OPERABILITY

\section{Definition}

BASES are pertinent information and details supporting IOSR elements and specific values or characteristics (see Appendix B, BASES).

$A$ unit of curie equivalency between transuranic and nontransuranic materials specific to the CWC. The CWC DE-Ci equivalency factors are calculated using the parameters for the worst-case accident scenario (fire release) and the parameters for the individual isotope. The CWC DE-Ci, for waste containing both TRU and nonTRU, is calculated in accordance with CWC procedures (Waste acceptance criteria as implemented by WHC-EP-0063 contains instructions for calculating CWC DE-C $i$ as described in Appendix E, HNF-SD-WM-ISB-007).

See Appendix A, DESIGN FEATURES.

See Section 1.6, MODES.

A system, subsystem, train, component, or device shall be OPERABLE or have OPERABILITY when it is capable of performing its specified safety function(s), and: a) actuation points are within limits, b) operating parameters are within 1 imits, and c) when all necessary attendant equipment, instrumentation, controls, electrical power sources, cooling water, lubrication or other auxiliary equipment that are required for the system, subsystem, train, component, or device to perform its specified function(s) are also capable of performing their related support function(s). 
$\underline{\text { Term }}$

VERIFY/VERIFIED/ VERIFICATION

\section{Definition}

An assessment to confirm or substantiate that specific facility conditions exist, and if not in this condition, ensure that a response is taken to satisfy the requirements. This may include collecting sample data or quantitative data; taking instrument readings; adjusting instrumentation set points; recording data and information on logs, data sheets or electronic media; and evaluating data and information in accordance with approved and controlled procedures.

VIOLATION See Section 5.1, IOSR VIOLATIONS.

\section{$1.2 \quad$ Logical Connectors}

NA for CWC.

[Not applicable to the CWC because there are no Limiting Conditions for operation and Surveillance Requirements]

\subsection{Completion Times}

NA for CWC.

[Not applicable to the CWC because there are no Limiting Conditions for Operation and Surveillance Requirements]

\subsection{Frequency}

NA for CWC.

[Not applicable to the CWC because there are no Limiting Conditions for Operation and Surveillance Requirements]

\section{$1.5 \quad$ Notes}

NA for CWC.

[Not applicable to the CWC because there are no Limiting Conditions for Operation and Surveillance Requirements] 


\section{$1.6 \quad$ Modes}

The MODES identified below are to be applied individually to each of the following Central Waste Complex facilities:

Waste Receiving and Staging Area

Mixed Waste Storage Pad

Low Flashpoint Mixed Waste Storagle Modules

Alkali Metal Waste Storage Modules

Mixed Waste Storage Facility

2401-W Building

2402-W Buildings

2403-W Buildings

2404-W Buildings

The MODES defined for the CWC are:

OPERATION

STANDBY

RESTRICTED
Activities involving waste packages are being performed in radiologically controlled areas. Waste packages are being received, inspected, handled, or moved.

No activities involving waste packages are being performed. Waste packages are in safe configuration. Routine surveillances and activities which do not involve waste package movement may be occurring.

No activities involving waste package handling or movement may be performed unless specifically required by an approved plan. 


\subsection{Safety Limits (SLs)}

SLs are limits on process variables associated with those primary physical barriers, generally passive, that are necessary for the intended facility function and found to be required to guard against the uncontrolled release of radioactivity that would result in unacceptable dose consequence to the public, as defined by ANSI 51.1 .

[Because of reliance on comprehensive AC, there are no SLs identified for the CWC, based upon the selection criteria in DOE Order 5480.22 and the conclusions found in the CWC ISB (HNF 1997)]

\subsection{Limiting Control Settings (LCSS)}

LCSs are settings on safety systems that control process variables to prevent exceeding Safety Limits (SLS).

[Since there are no SLS identified for the CWC there are no LCSs, based upon the selection criteria in DOE Order 5480.22.]

\subsection{Limiting Conditions for Operation (LCOS)}

LCOs are the lowest functional capability or performance level of safetyrelated structures, systems, components and their support systems required for normal safe operation.

LCOs shall be based upon maintaining the systems and structures OPERABLE or conditions within specified limits which are required for the protection of the public from unacceptable radiological consequences, as defined by ANSI 51.1.

[Because of reliance on comprehensive $A C$, there are no LCOs identified for the CWC based upon the selection criteria in DOE Order 5480.22 and the conclusions found in the CWC ISB (HNF 1997).]

\subsection{Surveillance Requirements (SRs)}

SRs are requirements relating to testing, calibration, or inspection to ensure that the necessary OPERABILITY and quality of safety-related structures, systems, components and their support systems, or specified conditions required for safe operation of the facility, are maintained.

[Because there are no LCOS identified for the CWC there are no associated SRs, based upon the selection criteria in DOE Order 5480.22. 


\subsection{Administrative Controls (ACs)}

ACs are the provisions relating to organization and management, procedures, recordkeeping, reviews, and audits necessary to ensure safe operation of the facility.

Facility specific programs and provisions are established as being necessary to ensure the safe operation of the CWC and include organization, criticality safety, and source strength control. 


\section{SECTION 2}

SAFETY LIMITS 


\subsection{Safety Limits (SLS)}

Because of comprehensive administrative controls, there are no Safety Limits (SLS) identified for the CWC based upon the selection criteria defined in Section 1.7, "Safety Limits." Additionally, there are no Limiting Control Settings (LCSS) because there are no SLs, based on the selection criteria defined in Section 1.8, "Limiting Control Settings." 


\section{SECTION 3}

LIMITING CONDITIONS FOR OPERATION 
3.0 Limiting Conditions for Operation (LCOS)

Because of comprehensive administrative controls, here are no LCOS

identified for the CWC based on the discussion in Section 1.9, "Limiting Conditions for 0peration." Additionally, the General Rules of Applicability for LCOs are not applicable. 
SECTION 4

SURVEIILLANCE REQUIREMENTS 
Section 4 SURVEILLANCE REQUIREMENTS

4.0 Surveillance Requirements (SRs)

There are no Surveillance Requirements identified for the CWC because there are no LCOs based upon the discussion in Section 1.10, "Survei11ance Requirements." 
SECTION 5

ADMINISTRATIVE CONTROLS 
Section 5 ADMINISTRATIVE CONTROLS

\subsection{IOSR VIOLATIONS}

\subsubsection{VIOLATION Criteria}

VIOLATIONS of the IOSR occur as the result of four circumstances:

a. Exceeding a SL [NA for CWC].

b. Failure to take the ACTIONS required within the required time limit following:

1. Exceeding an LCS [NA for CWC].

2. Failure to meet an LCO [NA for CWC].

3. Failure to successfully meet an SR [NA for CWC].

c. Failure to perform a Surveillance within the required time limit [NA for CWC].

d. Failure to comply with an $A C$ requirement.

An AC VIOLATION occurs: (a) when a required program has not been established; (b) when the program has been established but the facility has not attempted to implement the program; or (c) when failure to comply with the program requirements specified in 5.2.1, 5.3.1, and 5.4.1 results in CWC operations exceeding the analyzed authorization basis.

If during implementation of the required program it is discovered that a procedural element-other than those specified in 5.2.1, 5.3.1, or 5.4.1-was not performed or not followed, then a procedural noncompliance would result. An AC VIOLATION would not necessarily occur unless the noncompliance results in CWC operations exceeding the analyzed authorization basis.

5.1.2 Response to a Safety Limit VIOLATION

[Not applicable to the (WC)

5.1.3 Response to a Limiting Condition for Operation and Limiting Control setting VIOLATION.

[Not applicable to the CWC]

5.1.4 Response to a Surveillance Requirement VIOLATION

[Not applicable to the CWC] 
Response to an Administrative Control VIOLATION

If a VIOLATION of an AC occurs, proceed as follows:

a. Place the affected CWC facility in restricted mode and notify the DOE of the VIOLATION in accordance with DOE occurrence reporting requirements.

b. Prepare an Occurrence Report in accordance with DOE occurrence reporting requirements.

c. Prepare and implement a Recovery Plan describing the steps leading to compliance with the $A C$.

d. Perform and document a technical evaluation, if appropriate, of the AC VIOLATION to determine if any damage may have occurred.

e. Perform and document a root cause analysis and implement a corrective action plan, if appropriate, to minimize the chance of recurrence.

5.1.6 Response to an Administrative Control PROCEDURAL NONCOMPLIANCE

If a PROCEDURAL NONCOMPLIANCE of an AC occurs, proceed as follows:

a. Determine if the affected CWC facility needs to be placed in a restricted mode and if so notify the DOE of the PROCEDURAL NONCOMPLIANCE in accordance with DOE occurrence reporting requirements.

b. Prepare an Occurrence Report in accordance with DOE occurrence reporting requirements.

c. Prepare and implement a Recovery $\mathrm{Pl}$ an describing the steps leading to compliance with the $A C$.

d. Perform and document a technical evaluation, if appropriate, of the PROCEDURAL NONCOMPLIANCE to determine if any damage may have occurred.

e. Perform and document a root cause analysis and implement a corrective action $\mathrm{plan}$, if appropriate, to minimize the chance of recurrence.

\subsection{Organization}

\subsubsection{Contractor Responsibilities}

Lines of authority, responsibility, and communication shall be established and defined for the highest management levels through intermediate levels to and including all safety and operating organization positions. These relationships shall be documented and updated, as appropriate, in the form of organization charts, 
functional descriptions of departmental responsibilities and relationships, and job descriptions for key personnel positions or in equivalent forms of documentation.

The contractor shall be responsible for maintaining the current DOE approved IOSR as a controlled document.

The contractor is responsible for ensuring that the requirements of the CWC IOSR are met. Compliance shall be demonstrated by:

a. Operating within the Safety Limits (SLs) [NA for CWC],

b. Operating within the Limiting Conditions for Operation (LCOS), Limiting Control Settings (LCSS) and the associated Surveillance Requirements (SRs) during their Applicability [NA for CWC],

c. Operating within the ACTIONS of LCOS and LCSS when required [NA for CWC],

d. Performing all SRs as required [NA for CWC],

e. Establishing, implementing and maintaining the required ACs, and

f. Maintaining required DESIGN FEATURES. [NA for CWC]

The contractor is responsible for taking emergency actions that depart from the approved IOSRs when no actions consistent with the IOSR are immediately apparent, and when these actions are needed to protect the public health and safety. Such contractor actions shall be approved, as a minimum, by an operator or supervisor qualified through an approved training program. If emergency actions are taken which are not covered by existing emergency procedures verbal notifications shall be made in accordance with the DOE occurrence reporting requirements.

5.2.2 Central Waste Complex Manager*

The Central Waste Complex Manager shall be responsible for safe operation of the CWC. Safe operation shall include, as necessary, interface requirements with other onsite organizations and facilities.

*Facility Manager is defined as the Solid Waste Operations Team Lead (shift supervisor or supervision) or specifically assigned individual who is trained and qualified as an Operations Supervisor. 


\subsubsection{Minimum Operations Shift Complement}

The number of qualified shift managers and operators available shall be adequate to operate and support CWC activities safely. Minimum operations shift manager complement shall be based on the assigned shift Team Leader being available onsite. Abnormal conditions shall be considered in determining operator assignments. Management shall provide additional personnel, as necessary, to support other activities.

The minimum operations shift complement per shift for the entire CWC shall be as follows:

\begin{tabular}{|c|c|c|c|c|}
\hline & 10DE & $\begin{array}{c}\text { Shift } \\
\text { Manager }\end{array}$ & Operators & RCT \\
\hline \multicolumn{2}{|c|}{ OPERATION } & 1 & 1 & $\begin{array}{c}\text { as } \\
\text { required* }\end{array}$ \\
\hline \multicolumn{2}{|c|}{ STANDBY } & 0 & 0 & 0 \\
\hline \multicolumn{2}{|c|}{ RESTRICTED } & $\begin{array}{c}\text { as } \\
\text { required** }\end{array}$ & $\begin{array}{l}\text { as } \\
\text { required }\end{array}$ & $\begin{array}{l}\text { as } \\
\text { required** }\end{array}$ \\
\hline \multicolumn{2}{|l|}{$\star$} & $\begin{array}{l}\text { CWC operatin } \\
\text { t. }\end{array}$ & ocedures re & e an RCT to \\
\hline \multirow[t]{2}{*}{ 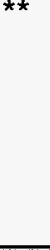 } & \multicolumn{4}{|c|}{$\begin{array}{l}\text { Staffing requirements shall be defined in the } \\
\text { specific Recovery Plan prepared when CWC has been } \\
\text { placed in RESTRICTED MODE. }\end{array}$} \\
\hline & \multicolumn{4}{|c|}{$\begin{array}{l}\text { Shift supervision is defined as the Facility } \\
\text { Operations manager, shift manager, supervisor, or } \\
\text { team leader (whichever is the direct shift } \\
\text { supervisor), or an assigned certified operations } \\
\text { management person. }\end{array}$} \\
\hline
\end{tabular}

The minimum complement $c$ an be 1 less than the required number for a period of time not to exceed 2 hours to accommodate unexpected absences, provided immediate action is taken to restore the shift complement to within the minimum shift requirements. 


\subsubsection{Support Organizations}

The contractor shall maintain organizations that provide safety overview and quality assurance functions to ensure safe operation of the facility.

5.2.5 Audit Point

A letter is issued to file at least annually from the Manager, Solid Waste Management describing the organization, lines of authority, responsibilities and any changes in key personnel or responsibilities as required by Section 5.2.1.

\subsection{Nuclear Criticality Safety}

\subsubsection{Requirement for Nuclear Criticality Safety}

A program shall be established, implemented and maintained to prevent an accidental criticality in CWC. The fissile material reactivity shall have a k-effective plus two standard deviations of 0.95 or less.

\subsubsection{Program Key Elements}

a. The nuclear criticality safety program maintains a fissile materials inventory compliant with the classification as a Limited Control Facility in accordance with WHC-CM-5-36, Chapter 4-29, "Nuclear Criticality Safety Manual." The current CPS covering the operations of the Central Waste Complex is CPS-5W-149-00002 (WHC 1995) or latest revision.

b. In the event a CPS requirement is not met, notification will be immediate and will include the CWC manager and the manager of Criticality and Radiological Analysis. The cause of the deficiency will be determined and a course of action to correct the problem will be implemented. A determination will be made as to whether the criticality safety requirement in Section 5.3.1 above for CWC has been exceeded.

c. The information and reports for determining fissile amounts of containers/material, together with container placement records, will be retained demonstrating that the CPS requirements are being maintained.

\subsubsection{Applicability}

This program applies to all areas within the CWC complex. 


\subsubsection{Audit Point}

An annual review of the CWC criticality safety program will be conducted by the facility's criticality safety representative. The annual review will evaluate results of the quarterly criticality safety inspections and the annual CPS review as specified in WHC-CM-5-36, Chapter 4-29 to verify the requirements outlined in Section 5.3.1 are being met. The results of this annual review will be documented and retained by the facility's criticality safety representative, and forwarded to DOE for information.

\subsection{Source Strength Control}

\subsubsection{Requirement for Source Strength Control}

A program shall be established, implemented and maintained to ensure that radioactive concentration limits and packaging limits assumed in the CWC ISB (HNF 1997) accident analys is will not be exceeded. The following summarizes the radioactive concentration and packaging limit that ensures the preclusion of unacceptable exposure to any offsite individual:

- Maximum single drum limit of 150 Dose Equivalent Curies (DE-C $i$ ) and inventories per zone within the limits of the CWC ISB, Section 5.9.2 (HNF 1997) ensures that the consequences of the most limiting accident will result in doses less than the risk comparison guidelines.

- A maximum limit of 4,600 Dose Equivalent Curies (DE-Ci) is allowed in each Low Flashpoint Mixed Waste Module.

\subsubsection{Program Key Elements}

The program key elements include the following:

a. The source strength control program prevents potentially significant onsite and offsite dose consequences in the event of an accident by ensuring that the solid radioactive waste materials remain within the inventory limits analyzed in the accident analyses. The accident analyses evaluate radioactive waste at maximum concentration and drum inventory as specified in the requirement of Section 5.4.1. The resultant consequences, without credit for mitigating features, are less than the risk comparison guidelines of Section 5.1.l (HNF 1997). The analyses show that the resultant onsite and offsite doses are acceptable.

b. This program shall also establish and maintain the radioactive inventories, concentration limits, receipt and packaging limits assumed in the CWC ISB (HNF 1997), such that the CWC continues to operate at inventory limits such 
that accidents do not yield consequences above the risk comparison guidelines (Table 5.1 of ISB). Operation at levels in excess of this control may be conducted with DOE concurrence.

The average radionuclide content of storage containers are expected to be maintained below $53 \mathrm{DE}-\mathrm{Ci} /$ drum equivalent volume. Latitude is allowed for a limited number of containers to exceed the $53 \mathrm{DE}-\mathrm{Ci} /$ drum equivalent volume; however, the remaining container quantities are required to be lowered accordingly such that the average for the building or a zone remains at or below the limits in Section 5.9.2 (Figure 5-3 of ISB). Waste containers that have been evaluated as having no credible accident scenario for radiological or toxicological releases are exempt from the CWC DE-Ci limit (e.g. Radioisotope Thermoelectric Generators and CR-Vault Tank Filter Assembly).

The aforementioned latitude is described explicitly in the CWC ISB, which incorporates the concept of zones. A zone being a unit of area holding storage drums, defined as a minimum of $46 \mathrm{~m}^{2}$ (500 $\mathrm{ft}^{2}$ ) with a minimum dimension of $6 \mathrm{~m}$ $(20 \mathrm{ft})$. A building or storage pad could be divided up into a number of zones, which facilitates the determination of dose consequences using conservative accident conditions.

The relationship between individual bounding uniform quantities in the remaining drums being stored in two adjacent zones and the quantity allowed in each drum exceeding the $53 \mathrm{DE}-\mathrm{Ci}$ is a linear function, as defined in the CWC ISB, section 5.9.2. The assumption is made that the quantity of the remaining drums remains constant for this relationship and this requires a separate 1 inear function to be produced for each additional drum exceeding $53 \mathrm{DE}-\mathrm{Ci}$. (See CWC ISB, Figure 5-3).

c. In the event the packaging, concentration, and inventory requirements defined above are not met, notification will be made in accordance with DOE notification requirements and will include the CWC manager. The cause of the event will be determined, and a course of action to correct the problem will be implemented. In the event that the packaging, concentration and inventory requirements are not maintained, the impact on safety at the facility will be determined immediately and corrective action will be taken to remedy the situation and prevent reoccurrence.

d. Packaging, concentrations, inventories, and locations of containers and material will be tracked in the Solid Waste Information Tracking System (or an equivalent program) to support demonstration that the requirements shown above are being maintained. 
e. Packaging, concentration, and inventory requirements for packages and material destined for the CWC are implemented through the Hanford Site Solid Waste Acceptance Criteria, WHC-EP-0063 (WHC 1993) or latest version. WHC-EP-0063 specifies criteria to ensure waste packages are within the assumptions for disposal as documented in the CWC safety analys is (HNF 1997). Also, WHC-EP-0063 implements waste package criteria for ensuring long term performance of the disposal system and for other dispositions of waste via storage and treatment. This operating document is an external procedure and will be updated as needed to maintain information and 1 imits current. Changes to this document will be evaluated using the Unreviewed Safety Question screening process.

\subsubsection{Applicability}

This program applies to all areas within the CWC complex.

\subsubsection{Audit Point}

Records are maintained that document inventories and concentrations present in CWC are consistent with Section 5.4.1. These are retained for a minimum of two years at the facility. 
This page intentionally left blank 
SECTION 6

REFERENCES

6-1 
These references are for the IOSR and its Appendices.

DOE 1992, Technical Safety Requirements, DOE Order 5480.22, U.S. Department of Energy, Washington, D.C.

DOE 1994, DOE Standard, Preparation Guide for U.S. Department of Energy Nonreactor Faci7ity Safety Analysis Report, DOE-STD-3009-94, U.S. Department of Energy, Washington, D.C. Washington.

HNF 1997, Central Waste Complex Interim Safety Basis, HNF-SD-WM-ISB-007, Rev. $0-A$, Westinghouse Hanford Company, Richland, Washington.

WHC 1993, Hanford Site Solid Waste Acceptance Criteria, WHC-EP-0063-4 (or current revision), Westinghouse Hanford Company, Richland, Washington.

WHC 1995, Central Waste Complex Criticality Prevention Specification, CPS-149-00002, Westinghouse Hanford Company, Richland, Washington.

WHC-CM-5-34, Solid Waste Disposal Operations Administration, Westinghouse Hanford Company, Richland, Washington

WHC-CM-5-36, Solid Waste Disposal Internal Requirements, Westinghouse Hanford Company, Richland, Washington 
HNF-SD-WM-TSR-005 REV 0

Appendix A

Design Features

APPENDIX A

DESIGN FEATURES

A-1 
As stated in DOE Order 5480.22 (DOE 1992), the purpose of the DESIGN FEATURES Appendix is to describe in detail those features not covered elsewhere in the TSR that, if altered or modified, would have a significant effect on safety. The areas to be addressed are vital passive components, configuration and physical arrangement, and materials. The following definitions were taken from DOE Order 5480.22 (DOE 1992):

a. Vital passive components are essentially piping, vessels, supports, structures (such as confinement) and containers.

b. The DESIGN FEATURES Appendix should also address configuration and physical arrangement, where it is a safety concern.

c. If safe operation of the facility is dependent on any component being constructed of a particular material, that requirement should be discussed in the DESIGN FEATURES Appendix.

d. Site characteristics such as the locations of public access roads, collocated facilities, facility area boundaries, site boundaries, nearest residence distances, etc., should be presented in the DESIGN FEATURES Appendix.

As indicated in the paragraphs above and based on the information presented in the CWC ISB (WHC 1996), there are no additional DESIGN FEATURES for the CWC (i.e. design features that are not covered elsewhere in the IOSRs that, if altered or modified, would have a significant effect on safety). Significant safety features described in the CWC ISB (i.e., criticality, material at risk, container criteria, etc.) and any changes to these are covered by ACs 5.3 and 5.4 . 
APPENDIX B

BASES

B-1 
[Not applicable to the CWC since there are no SLS, LCSs, LCOS or SRS]

This Appendix provides summary statements of the reasons for the Safety Limits, Limiting Conditions for Operation and the associated Surveillance Requirements. The BASES describe how the limit(s), the Applicability, the Condition(s) and the Surveillance(s) will maintain operation within the authorization basis. The primary purpose for describing the BASES for these requirements is to provide the operations and engineering staff with the necessary information to maintain the CWC within the authorization basis and to ensure that any future changes to these requirements will not affect their original intent or purpose. 


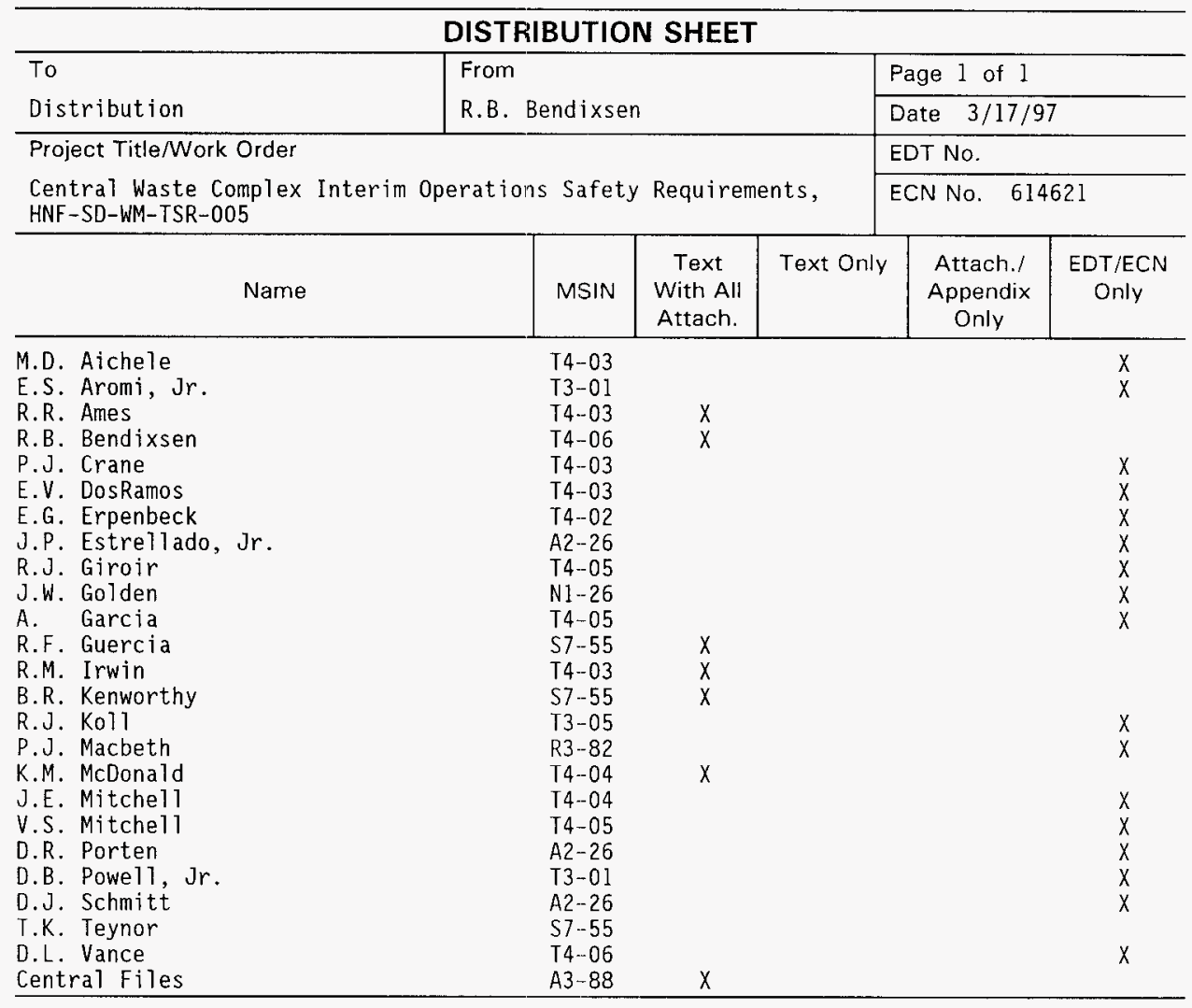

